Volume 8

Number 1 Fall 2020 Symposium Edition Local

Citizens in a Global Age

Article 2

$12-29-2021$

\title{
Questions of Citizenship and the Nature of "The Public"
}

Sarah Schindler

University of Denver, sschindler@law.du.edu

Follow this and additional works at: https://scholarship.law.tamu.edu/journal-of-property-law

Part of the Law and Society Commons, Property Law and Real Estate Commons, and the Public Law and Legal Theory Commons

\section{Recommended Citation}

Sarah Schindler, Questions of Citizenship and the Nature of "The Public", 8 Tex. A\&M J. Prop. L. 19 (2021). Available at: https://doi.org/10.37419/JPL.V8.11.2

This Symposia Article is brought to you for free and open access by Texas A\&M Law Scholarship. It has been accepted for inclusion in Texas A\&M Journal of Property Law by an authorized editor of Texas A\&M Law Scholarship. For more information, please contact aretteen@law.tamu.edu. 


\title{
Questions of Citizenship AND the Nature of "The Public"
}

\author{
Sarah Schindler ${ }^{\dagger}$
}

\section{INTRODUCTION}

This essay is taken from a talk given at a symposium discussing Professor Ken Stahl's book, Local Citizenship in a Global Age. ${ }^{1}$ It is not a traditional book review, but rather a series of musings inspired by the ideas in the book.

Professor Stahl's new book, Local Citizenship in a Global Age, addresses a number of important issues, many of which have been the focus of my prior work: the existence of boundaries, borders, and the spaces in between; who we include in those boundaries and who we exclude; public space, private space, and the lines between them; spaces of production versus those of consumption; and questions of place and authenticity. Thus, I was excited to participate in a discussion of the book. This essay focuses specifically on Part III of Stahl's book, which addresses "Race, Space, Place, and Urban Citizenship."

In addition to the topics I mentioned above, Professor Stahl's book is about citizenship. Indeed, it is primarily about citizenship. But, as Professor Stahl describes various conceptions of citizenship, it is clear that the reader has to grapple with all of the other issues I notedboundaries, place, exclusion - in order to fully understand citizenship.

This essay provides no broad critiques or sweeping analysis. Rather, it will discuss the concepts that struck me in the book and the ideas it made me think about. Thus, what follows are some thoughts, organized generally in the order in which they came to me as I was reading Part III of the book.

DOI: https://doi.org/10.37419/JPL.V8.I1.2

${ }^{\dagger}$ Sarah Schindler is the Maxine Kurtz Faculty Research Scholar \& Professor of Law at the University of Denver Sturm College of Law. She is also the Director of Denver Law's Environmental and Natural Resources Law Program.

1. Kenneth A. Stahl, Local Citizenship in a Global Age (2020). 


\section{URBAN CITIZENSHIP}

Professor Stahl begins by talking about "urban citizenship" broadly. In contrast to liberal local citizenship-which treats urban space as fungible, undifferentiated, and interchangeable - urban citizenship is deeply connected to a defined sense of place. ${ }^{2}$ This type of citizenship is practiced when people take over private or public spaces for political, organizational, or even leisure purposes. ${ }^{3}$ Urban citizenship envisions the public as "a place where people come together to socialize rather than consume." "In this place, people are "thrown together in all their diversity." Jerry Frug described these places as the ones where we encounter "unfamiliar kinds of strangers." By encountering and engaging with these strangers in public space, people open themselves up to "unprogrammed" discussions and "diverse viewpoints."7 Thus, the idea is that urban citizenship is made possible by the existence of "places for meaningful social interaction" and is rooted in place. ${ }^{8}$

I see two main problems with this underlying conception of public space, and place more broadly. First, much of our public space now, even in urban areas, is privatized-either public property that is operated or controlled by private entities (like the Business Improvement Districts mentioned in the book), or privately owned public open spaces ("POPOS"), which make up most of the newly produced public space in many cities. ${ }^{9}$ Many commentators, including social scientists and geographers, have recognized that privatized public space is problematic and a poor substitute for traditional public space. ${ }^{10}$ It is exclusionary, segregationist, and sterile. It diminishes opportunities for free speech and prevents people from different classes and backgrounds from interacting with one another. ${ }^{11}$ Further,

2. Id. at 171 .

3. Id. at 170 .

4. Id. at 171 .

5. Id.

6. Gerald E. Frug, Citizens and Property Rights, ReVISTA: HaRV. ReV. OF LATIN AM. (Winter 2003), https://archive.revista.drclas.harvard.edu/book/citizensand-property-rights [https://perma.cc/JK9V-JAVQ].

7. Sarah B. Schindler, The "Publicization" of Private Space, 103 IowA L. REV. 1093, 1102 (2018) [hereinafter “Publicization”'] Jeremy Németh, Defining a Public: The Management of Privately Owned Public Space, 46 URB. STUD. 2463, 2463 (2009).

8. STAHL, supra note 1 , at 171.

9. Publicization, supra note 7 at 1095.

10. Id. at 1097 .

11. Id. 
there is a fear of loss of democratic process when corporations and other private entities control public spaces and the public realm more than citizens do. ${ }^{12}$

A second concern is that, as Stahl points out, throughout history many people have been and continue to be excluded from public and quasi-public space (even that which is not privatized). ${ }^{3}$ As Don Mitchell has noted, "the streets and parks of the city, like the Greek agora, Roman forums, or 18th-century German coffeehouses before them, have never simply been places of free, unmediated interaction. ${ }^{14}$ Rather, they have always also been spaces of exclusion."15 Margaret Crawford recognized that the agora was closed to women and people who were enslaved, and that current public space privileges what she calls "middle-class and masculine modes of public speech." 16 This is especially problematic, given that public space offers one of the only locations for people who lack access to other places (like a house or a place of employment) to exist. People who are unhoused comprise the most obvious segment of society that needs and depends on public space in this way. They must rely on public space "as a refuge, as a place to sleep, as a stopping point, as a place of community and conviviality."17 Given this reality, any conception of citizenship that relies on this idea of the public and public space is less open and inclusive than it might purport to be.

\section{REPUBLICAN CITIZENSHIP}

Professor Stahl suggests that republican citizenship involves attempts to draw walls around communities, which can result in xenophobia and nativism. ${ }^{18} \mathrm{He}$ recognizes that "exclusion lies at the very core of republican ideology." 19 For example, Stahl speaks of the exclusion of women, people of color, and foreigners from the public and politics. $^{20}$

12. Id.

13. STAHL, supra note 1 , at 168.

14. Don Mitchell, The Right to the City: Social Justice And the Fight FOR PUBliC SPACE 131-32 (2003).

15. Id. at 132 .

16. Margaret Crawford, Blurring the Boundaries: Public Space and Private Life, in EVERYDAY URBANISM 344 (John Leighton Chase, et al. eds., expanded ed. 2008).

17. MitCHELL, supra note 14 , at 15 .

18. STAHL, supra note 1, at 229.

19. Id. at 186 .

20. $I d$. 
But thinking back to the earlier discussion of public space, we see that this is not mere political exclusion or exclusion from citizenship; the exclusion is also often physical and architectural. Especially when we are talking about concepts of space and place, we must keep in mind that many tools of exclusion have been concrete rather than conceptual. The design of the built environment is full of exclusionary examples: the use of guard desks at the entrance to public space, the failure to build sidewalks or post directional signage in exclusionary neighborhoods, and the use of one-way streets to keep outsiders out, to name a few. ${ }^{21} \mathrm{We}$ have built our cities in such a way as to keep the "other" out of many public spaces, even though that "other" is in fact a member of the community.

In this part of the book, Stahl builds on this idea by describing the way that republican-minded theorists view exclusionary suburbs. He notes that they reject the public streets and sidewalks in which people congregate, favoring shopping malls. ${ }^{22}$ This view leads us to see the exclusionary suburbs as "not real places, in the sense of authentic communities with a deep sense of connection to the territory, but inauthentic "places of consumption.", 23

Of course, many people are working toward the densification of the suburbs, turning malls into mixed use developments and constructing outdoor lifestyle centers that replicate sanitized versions of traditional downtowns. ${ }^{24}$ As Stahl later notes, the suburbs are not all as exclusionary as they once were - many are now more diverse than their associated city centers. ${ }^{25}$ Indeed, in the book's conclusion, Stahl gives a different view, noting, "[t]he irony thus is that our cities have places but lack diversity, while suburbs have diversity without places." 26

Here, he also refers to the suburbs as "the most authentic sites of local citizenship." 27 But what does this mean? Because a place is

21. Sarah Schindler, Architectural Exclusion: Discrimination and Segregation Through Physical Design of the Built Environment, 124 YALE L.J. 1934, 1953 (2015) (describing many examples of this type of exclusion through infrastructure and physical design).

22. STAHL, supra note 1 , at 233.

23. Id. at 183 .

24. Sarah Schindler, The Future of Abandoned Big Box Stores: Legal Solutions to the Legacies of Poor Planning Decisions, 83 U. COLO. L. REV. 471, 494 (2012); June WiLliamson \& Ellen Dunham-Jones, CASE STUDiES IN RETROFITTING SubURBIA: URBAN DESIGN STRATEGIES FOR URGENT CHALLENGES (2021).

25. STAHL, supra note 1 , at 232.

26. Id. at 233 .

27. Id. at 232 . 
diverse, is that what makes it authentic? If it has no recent history and was created all at once, on land that likely was formerly farm land, what is its authenticity tied to? This topic alone could take up an entire book, ${ }^{28}$ but I do want to say a few words here about authenticity, place, and space.

Earlier in this Part, Stahl describes places of consumption as those that "evoke the authenticity of places, but whose sense of place has been manufactured in order to induce consumption," and thus, the interactions that people have with these spaces are shallow and inauthentic. ${ }^{29}$ I would argue that much of our public space, in both cities and suburbs, now feels sanitized and inauthentic. It often lacks what Henry Shaftoe described as "the rough edges [and] unpredictability that make true public space so vital and democratic." 30

Of course, these discussions of authenticity are more the province of urban sociologists than lawyers; only a few legal scholars have written about authenticity as it relates to law and space. ${ }^{31}$ Moreover, the question of what is authentic - and who gets to decide what is authentic-is itself somewhat problematic. ${ }^{32}$ One problem with authenticity as it relates to public space is that spaces that are perceived as authentic are sought after; they are thus colonized and gentrified, which often leads to a perceived lack of authenticity. ${ }^{33}$ This practice is not universally viewed with disdain however. Oftentimes today, people will seek places that look authentic, but not those that

28. See, e.g., Maria Francesca Piazzoni, The Real Fake: Authenticity AND the PRODUCTION OF SPACE (2018), JAMES H. GILMORE \& B. JOSEPH PINE II, AUTHENTICITY: WHAT CONSUMERS REALLY WANT (2007).

29. STAHL, supra note 1 , at 174.

30. Henry Shaftoe, Convivial Urban Spaces: Creating EFFECtive Public SPACES 77 (2008).

31. See, e.g., Lior Strahilevitz, Historic Preservation and Its Even Less Authentic Alternative, (U. Chi. L. Sch., Kreisman Working Paper Series in Housing Law and Policy, No. 41, 2016); Publicization, supra note 7; David J. Barron \& Gerald E. Frug, After 9/11: Cities, 34 URB. L. 583, 593 (2002) (mentioning "authentic urbanism"); see also Sig LANGEGGER, Rights TO PUBlic SPACE: LAW, CULTURE, AND GENTRIFICATION IN THE AMERICAN WEST 111 (2017).

32. Scott Barry Kaufman, Authenticity Under Fire, SCT. AM. (June 14, 2019), https://blogs.scientificamerican.com/beautiful-minds/authenticity-under-fire [https://perma.cc/P3PR-8S74] ("[T]here is a lack of consensus among both the general public and among psychologists about what it actually means for someone or something to be authentic.").

33. Publicization, supra note 7 , at 1130. 
feel or smell that way. ${ }^{34}$ This is likely why there is a demand for the "places of consumption" that Stahl describes.

\section{POST-MODERN CITIZENSHIP}

In the next part of the book, Stahl describes post-modern citizenship as that where people are "incorporated into political life by displaying their diverse identities in public places." 35 Here, I wonder how the ongoing COVID-19 pandemic might change our conceptions of both post-modern citizenship specifically and citizenship more broadly.

At least to the extent that citizenship is tied to place, it seems that our conceptions of it must change. Due to the pandemic, we can no longer be "in public" as we historically have been. We are currently limited in our interactions with both public space and other members of the public - especially strangers. Further, during this pandemic, more of our public space has been privatized, co-opted, and commercialized. ${ }^{36}$ For example, we have seen an expansion of seating for restaurants and bars into streets. ${ }^{37} \mathrm{In}$ an attempt to mitigate the harms associated with being indoors, municipalities have attempted to strike a balance between public health and the economic health of businesses. Thus, many cities and towns have allowed restaurants to seat patrons all over sidewalks and into the public streets and rights of way. Often, these seating arrangements are located where people traditionally walk, bike, or park their cars. These changes have been lauded by some for creating more interaction in public places and activating underused spaces. ${ }^{38}$ However, they really only create

34. Id.

35. STAHL, supra note 1 , at 196.

36. See, e.g., Jordi Honey-Rosés, et al., The Impact of COVID-19 on Public Space: An Early Review of the Emerging Questions - Design, Perceptions and Inequities, CITIES \& HEALTH 3, 5 (July 31, 2020), https://www.tandfonline.com/doi/full/10.1080/23748834.2020.1780074 [https://perma.cc/BR3U-YM7X].

37. Jane Margolies, Dining in the Street? As Restaurants Reopen, Seating Moves Outdoors, N.Y. TIMES (June 16, 2020), https://www.nytimes.com/2020/06/16/business/coronavirus-restaurants-outdoorseating.html [https://perma.cc/68X6-762B]; Sarah Schindler, Maine Voices: Expanded Outdoor Dining Must Make Room for Public in Public Spaces, PORTLAND PRESS HERALD (May 19, 2020), https://www.pressherald.com/2020/05/19/maine-voices-as-cities-move-to-expandoutdoor-dining/ [https://perma.cc/N7AB-XD34].

38. See, e.g., Anne Marie Sowder, How the Pandemic is Bringing Dining to Streets, Sidewalks, and Parking Lots in the United States, CTR. FOR EVIDENCEBASED MED. BLOG, (Aug. 24, 2020), https://www.cebm.net/2020/08/how-the- 
interactions for a certain segment of the population: specifically, those people who can afford to eat and drink in public during a deadly pandemic - both from a financial perspective and from a personal health perspective.

Again, this privatization of public space carries with it the risk of exclusion. Often, it is only paying restaurant or café patrons who are permitted to use the al fresco seating. This is especially ironic given that in many of these cities that now allow patrons of restaurants to take up space by sitting on the sidewalk while paying to eat, a person experiencing homelessness would not be allowed to camp on that same sidewalk. In many municipalities, even temporarily laying down or sitting to rest on a public sidewalk opens up the possibility of a fine or arrest under "move along" ordinances. ${ }^{39}$ This all ties into the idea of "commerce corrupting place," which Stahl mentions in this Part. ${ }^{40}$

In this section, Stahl also discusses people who have been marginalized "asserting themselves in public places" 41 _but again, this raises issues of privilege, safety, and exclusion. To what extent do marginalized people feel safe undertaking these activities"display[ing] difference and exhibit[ing] citizenship" in public? ${ }^{42}$ At base, it depends a lot on the type of place they are inhabiting - some places and communities will be more welcoming and others less. The ability to assert oneself in public also assumes that marginalized folks can gain physical access to these public places and are not physically excluded through various means I have already mentioned. ${ }^{43}$

Finally, in this chapter, Stahl discusses the "Disneyfication" of urban spaces, whereby they are sanitized. ${ }^{44}$ Through this process, he notes, "urban places are being deprived of the very qualitiesopenness, diversity, spontaneity - that would enable them to cultivate post-modern citizenship." 45 But here we must ask again: are those

pandemic-is-bringing-dining-to-streets-sidewalks-and-parking-lots-in-the-unitedstates/ [https://perma.cc/W4CD-WV8U] ("The expanded use of streets, sidewalks, and parking lots to include gathering and dining due to COVID-19-related physical distancing measures has the potential to improve the urban environment, and should be adopted permanently where practical.").

39. See, e.g., Tony Robinson, No Right to Rest: Police Enforcement Patterns and Quality of Life Consequences of the Criminalization of Homelessness, 55 URB. AFF. REV. 41, 48 (2019).

40. STAHL, supra note 1 , at 188.

41. Id. at 197.

42. $I d$.

43. See generally Publicization, supra note 7.

44. STAHL, supra note 1 , at 201.

45. Id. 
types of places - ones that foster openness and diversity - even real? Do they actually exist? Or are they idealized visions of what public space is, has been, or could be? This idea of the ideal is elaborated upon in the book's next chapter, which focuses on differentiated citizenship. ${ }^{46}$

\section{DIFFERENTIATED CITIZENSHIP}

In this chapter, Stahl references a "[c]ommitment to an ideal of community" and the "normative ideal of city life." 47 This framing seems to recognize that many of our conceptions of cities and communities are ideals rather than on-the-ground reality. But what good are our theories of citizenship if they are based on ideals and not founded in the reality of the city? These same questions and concerns arise with respect to the nature of public space and concepts of place. ${ }^{48}$ Many people have an idealized vision of public space: what it ought to be, who it ought to be for, and what values it should serve. The reality is that public space does not always build community and foster discourse among diverse segments of the population-it is often exclusionary, as Stahl explains. ${ }^{49}$ Thus, this reality must be taken into account if citizenship is going to be tied to space, place, and our views of "the public."

Finally, Stahl talks about liberal citizenship with respect to Tiebout's consumer voter model. ${ }^{50}$ Commentators have long criticized this model as illusory, ${ }^{51}$ and Tiebout himself acknowledged as much. ${ }^{52}$ We know that it is not easy for people to pick up and move- especially poor people. ${ }^{53}$ Further, we know that people are not specifically

46. Id. at 208 .

47. Id. at 211.

48. See Publicization, supra note 7, at 1104.

49. STAHL, supra note 1 , at 200.

50. Id.

51. Clayton P. Gillette, Reconstructing Local Control of School Finance: A Cautionary Note, 25 CAP. U. L. REV. 37, 40 (1996) ("the Tiebout world, however, is obviously not the world in which we live"); JONATHAN LEVINE, ZONED OUT: REgulation, Markets and ChOICES in TRANSPORTATION AND METROPOlitan LAND-USE 68-70 (2006) (discussing the interplay of zoning with the model).

52. Charles M. Tiebout, A Pure Theory of Local Expenditures, 64 J. POL. ECON. 416, 419 (1956) (describing the model as "extreme").

53. Laurie Reynolds, Intergovernmental Cooperation, Metropolitan Equity, and the New Regionalism, 78 WASH. L. REV. 93, 104-05 (2003) (noting that the "lack of affordable housing in suburban areas makes moving an illusion even for many moderate-income individuals who are willing and able to assume the costs of the move"). 
choosing a city that has bad schools and inadequate services. ${ }^{54}$ The idea of choice here is an illusion.

Stahl also points out that the Supreme Court has refused to strike down local zoning regulations that "restrict the development of housing and thereby make it exceedingly difficult for people (especially of lesser means) to establish residence in wealthier communities." 55 But, of course, it goes beyond this. Stahl notes that "a principle feature of liberal local citizenship is the right to travel" and the idea of free mobility. ${ }^{56}$ But cities have long limited the free mobility of their citizens through means other than law. ${ }^{57}$ Specifically, I am thinking of limitations on mobility through architecture and infrastructure of the built environment, and through norms.

\section{CONCLUSION}

Much of Professor Stahl's book focuses on the nature of "the public." In many ways, "the public" is defined by who is excluded; this is true for public space as well as the public realm of citizenship. ${ }^{58}$ Thus, Stahl wrestles with the important question of whether we can expand our ideas of who is (and should be) included in the public without losing a sense of tight-knit belonging that seems to be psychologically necessary for some people. As Professor Stahl has written about previously, across the country we have seen suburban, single-family-zoned neighborhoods bristle in response to the idea of building additional housing or allowing multi-family development asof-right. ${ }^{59}$ These existing community members often see the expansion of membership in their community as a threat. Similarly, as Stahl discusses in this book, expanding rights to noncitizens-for example, by opening up borders - is seen as a threat to whiteness and to white peoples' conceptions of the public, the community, and the

54. Frug, supra note 6, at 31 ("People who live in unsafe neighborhoods or send their children to inadequate schools don't do so because they have taste for them . ... If they had a choice . . . they would prefer better schools and less crime.").

55. STAHL, supra note 1, at 219.

56. Id.

57. Kia Rahnama, The Right to Move Freely, SLATE (Jan. 13, 2020 9:00 AM), https://slate.com/news-and-politics/2020/01/right-to-free-movement.html [https://perma.cc/ZQ9Y-JG5M].

58. STAHL, supra note 1 , at 96.

59. Lisa Prevost, A Push for Zoning Reform in Connecticut, N. Y. TIMES (Feb. 26, 2021), https://www.nytimes.com/2021/02/26/realestate/connecticut-zoningreform.html [https://perma.cc/5B94-R8V8]. 
self. ${ }^{60}$ In writing this book, Stahl delves into ways that we might start to push back against these exclusionary tendencies.

60. Elizabeth Oh, American Immigration Laws Have Always Been About Preserving Whiteness, NEW AM. (Sept. 22, 2020), https://www.newamerica.org/weekly/american-immigration-laws-have-alwaysbeen-about-preserving-whiteness/ [https://perma.cc/F3MD-B3R7]. 